\title{
在宅个了: 入浴少フ夕一利用による患者・家获の满足感
}

$\mathrm{O}$ 土屋 紀子

( 自治医科大学看護短期大学)

はじめに：

厚生省の高齢者用介護機器の二ーズ調査では自立・介護支援機器ともに入浴支援の機 器開発に対する二ーズは高い。今回、通産省支援で開発された入浴入浴リフ夕一患者・ 家族介護者の二ーズを満たしているか。理念を踏襲できたか。研究開発の基本理念は(1) 身体的・精神的機能の維持、(2)自立の重視、（3）人間性の尊重、(4)人間之機械の役割分 担、(5)使用者の身体状況への配慮、(6)使用環境への配慮の重視である。そこで、今回は 以下の研究目的を設定した。

研究目的：(1)入浴リフターは実際、開発基本理念 (1) 〜 (6) を満たし、患者・家族の Q O L・ニーズに対応しているかを検討する、（2）入浴リフターの安全性、簡易・簡便 性、コスト・満足感の調查研究を実施することで生産者・使用者・医療者の三者側から の意見を相互に交換・反映させて、患者へのサービスと質を高める。

入浴リフターとは：(1)通産省の研究委託を受けて開発された入浴の自立・介護支援機 器である、(2)上水道設備の条件下で浴室に三方の梁があれば改造の必要なくリフトを付 設できる、(3) $80 \mathrm{~kg}$ の重さまで可、リフトハンガーで患者を浴槽に移乗できる、(4)リフト の上下は水道圧でポンプ操作できるので、電気工事の必要はない、(5)操作方法は容易で、 その学習はきわめて簡単である。

研究方法：1. 対 象：入浴リフター(マ仕180)を購入した患者の家族 100 名、2. 調查期間：平成 8 年 4 月 29 日〜 5 月 6 日、 3 . 調查方法：自他記式アンケート（4点尺 度の満足感などの調查）、4。回収率：37\%(37/100)。

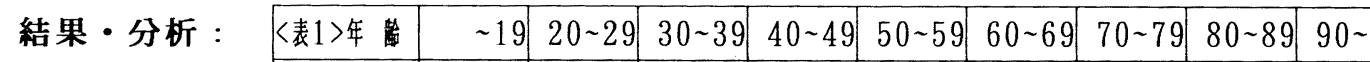

\begin{tabular}{rl|l|l|l|l|l|r|r|r|r|} 
1. 性別：患者の & 患者 & 1 & 2 & 3 & 3 & 1 & 8 & 15 & 2 & 2 \\
\cline { 2 - 11 } & 性別は男性21名で者 & 0 & 2 & 2 & 8 & 3 & 12 & 6 & 1 & 0 \\
\hline
\end{tabular}
女性は16名であった。主に介護をし

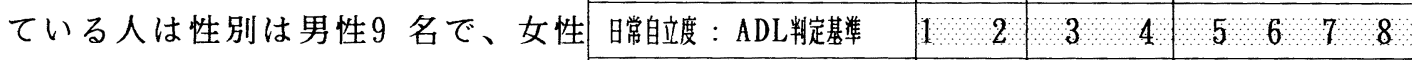

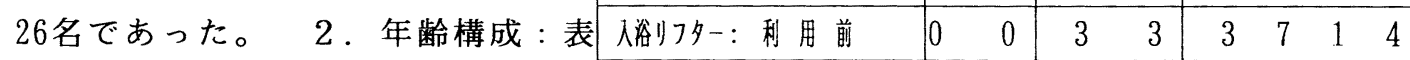

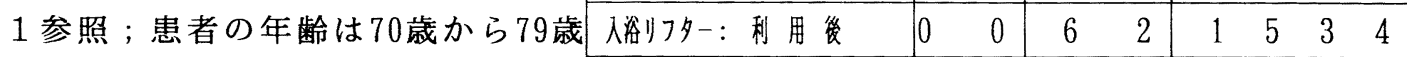
の15名が最も多く、介護者は 60 歳から69まで〈表3〉 (注)（）内は入浴リフター利用後

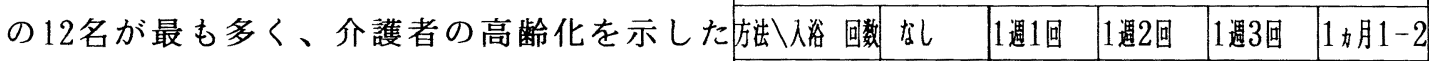

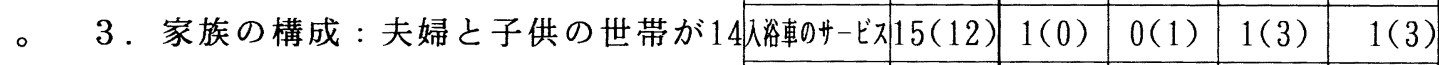

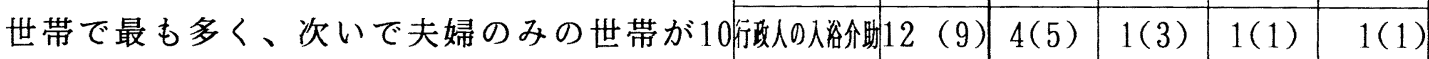

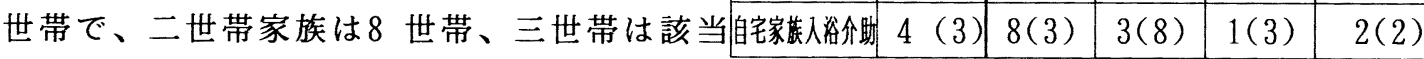
者なしであった。 4 . 患者の障害の原因：疾病別では脳血管障害が最も多く10名で、 次は 神経系疾患が 4 名, 脊䯣損傷、リウマチの疾患など計 15 名であった。 5 ．介護 
者：家族のなかでは妻が10名で最も多かったが、家族外（近隣者・友人等）は14名でさ らに多かった。6. 入浴状況：表 3 参 照; 入浴リフター利用後は自宅の 1 週の 入浴回数が増加しており、行政の入浴車 と人的の利用も増加してきた。入浴する ことが容易であると4点尺度でM 平均值 3.

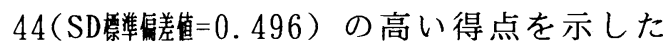

7. 清潔ケア：入浴による清潔ケア でM3.57（SD=0.496）の高得点を得た。褛 そうの回復は $3.15(\mathrm{SD}=0.769)$ と高い。介 護者の清潔ヶアの満足感はM3.5

$5(\mathrm{SD}=0.498)$ を得た。 8 。自立度：表 3 は A D L 状況を示したが、入浴リフタ 一だけの効果の有無は難しく、Nも過小 であるため分析困難であった。患者は脊 䯣損傷、脳神経神経系疾患などから片麻 痺11名、四肢及び下半身麻痺7名、首部 または胸部レベルからの麻痺10名等、重 い障害者が多いが、入浴リフター利用後 、自立度が上昇したと介護者の回答した 割合は、75.6\%(28/37)に認め 4 点尺度の 度合いでは平均値 $\mathrm{H} 2.71(\mathrm{SD}=1.044)$ を示

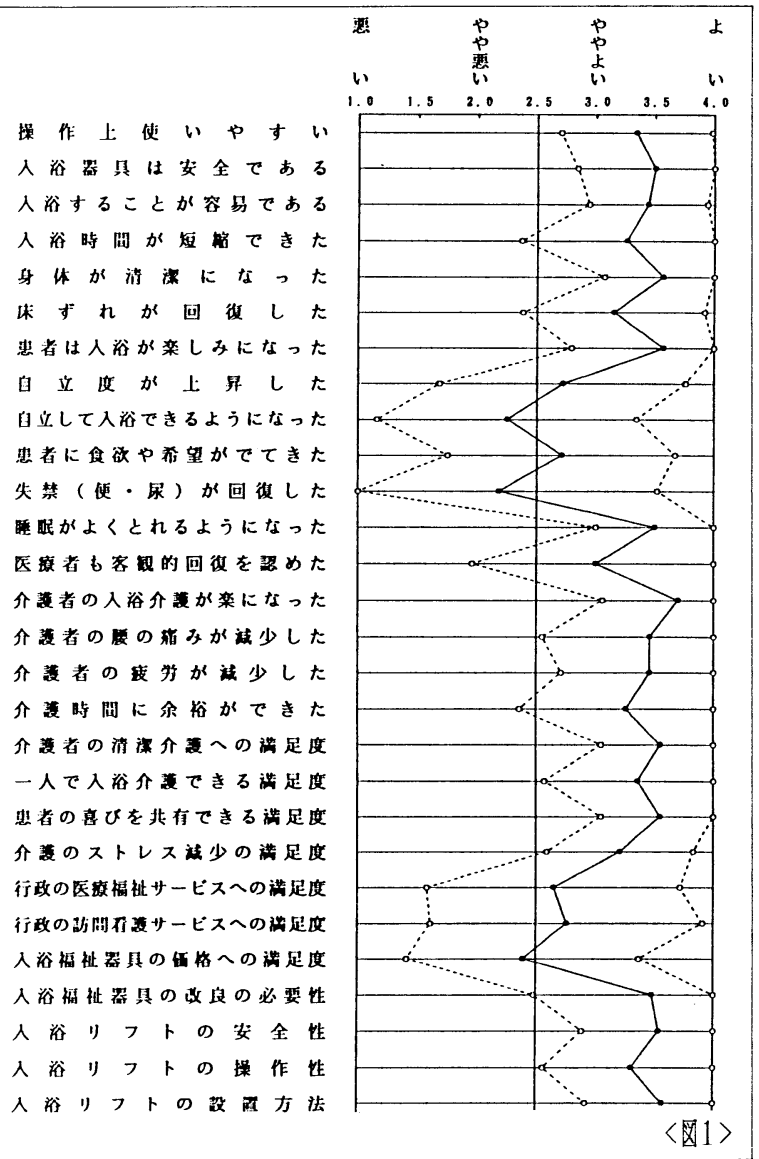
〈图1〉 した。医師の評価ではM3.0 ( SD=1.038)であった。9.入浴リフター利用の満足感：患 者の入浴の楽しみ $3.57(\mathrm{SD}=0.776)$ 、家族介護者ともに満足感が高く、介護の安楽 $\mathrm{H} 3.7$ $(\mathrm{SD}=0.64)$ で最高得点を示した。さらに介護者の疲労、腰痛、ストレス等の心身の苦痛 の軽減もはかれ、時間の余裕も示された。重度の障害で患者のA D L は低下したが入浴 リフターで自宅のお風呂に入浴できる喜びが患者・介護者共に素直に表出されている。 入浴で患者は適度な疲れを得て、生活のリズムがつき睡眠にも効果 M 3. 5( SD=0.50) を与 えた。 10 . 入浴リフターそのものの安全性 $\mathrm{H} 3.54(\mathrm{SD}=0.643)$ 、操作性 $\mathrm{H} 3.31(\mathrm{SD}=0.7$ 47）、設置方法M3.57(SD=0.645) とそれぞれ高い評価を示した。 11 . 行政のサービ ス: 補助金全額支給は 7 名、一部負担は 18 名であった。浴室の改装は 15 名でその内 3 名はの全額支給で満足度に幅 $1.149(\mathrm{SD}=1.072)$ を示した。人的サービスでは、期待と 現実のギャップのためか $2.76(\mathrm{SD}=1.151)$ を示した。

評価・検討：福祉用具開発の基本理念の 6 項目検討は、この調査研究においてそれぞ れ評価できる得点を得られたが、回答が遅延して調查研究の質に問題を残した（介護者 の高年齢化、家事労働多忙等も推測される）。調查方法・内容共に再検討課題である。 患者が自宅で、心身の回復を得られる医療福祉機器サービスの開発推進の基本にして、 今後も患者、医療関係者、生産者間交流のある研究を進める。 